\title{
TOURIST AS A PEACE AMBASSADOR: A CREATIVE TOURISM PERSPECTIVE IN ASIA COMMUNITY
}

\author{
Abdillah Nugroho \\ Universitas Muhammadiyah Surakarta \\ Surakarta, Indonesia \\ abdillah nugroho@ums.ac.id
}

\begin{abstract}
Undoubtfully tourism in Asia can give a significant contribution in economic income for both countries and their people. Many countries in Asia attract tourists from over the world to visit their countries in a variety of efforts. Beside providing a good service, infrastructures and beautiful tourism destination, they also promote their tourism objects and destination by means of social media, television, brochure and many other advertisement. Through tourism, countries in Asia compete each other to raise their economic income. In short, countries in Asia see tourism industry as an economic commodity. On the other hand actually not only does tourism give impact on economic development of the countries and its people but it also gives a strategic influence on peace-making in Asia area. By tourism, the tourists can learn culture and tradition of the people. When visiting a community in this region, they can understand a certain value, norm and a particular belief of the people and many others. By doing so, it will ignite a mutual understanding among the people of the nations. Thus tourism can decrease the tension or conflict among countries in Asia. Problems among countries in Asia are various. They can be political, social, cultural, economic as well as religious. Commonly the leaders in Asia countries solve them through diplomacy approach. They send envoys to discuss and wipe out their conflicts. Sometimes it takes a long time to get deal and involves a limited number of person. In the near future, tourism might take a significant role in eliminating the various problems faced by the leaders in Asia. An appropriate type of tourism that might give a strategic impact on creating the region peaceful is a creative tourism. The basic concept of the creative tourism lies on a paradigm that tourist is not just a spectator and engaging in sightseeing, but also involves a reflexive interaction on the part of tourist. It indicates that as a tourist, they not only enjoy the hospitality of the people and the beauty of scenery they visit, but they also make an interaction with the local people and do something accustomed to being done by the people in that place at a certain period of time. They try to learn the people's habit, creation and tradition and also understand their belief system. The Asia countries and the people in this region are required to be creative to offer an attractively creative tourism. They might create a certain area as an integrated creative tourism agenda. In this area, the tourists can stay with a certain community in a particular term of time. They interact with the local people in their day-to-day activities. They try to communicate with them with their language. They can also practice a certain skill usually done by the people, such as making a handy craft, producing a certain type of food and beverage and what not. They can share their different life habit and culture. By doing so, the tourist can get some experiences and understanding. Those aspects are able to generate and develop a mutual relationship among the people
\end{abstract}

and finally it can strengthen a feeling of peace among the people in this region. Through creative tourism, peace-making mission will be pushed to be a primary agenda in Asia tourism policy in the near future.

Keywords - tourism industry, economic commodity, creative tourism, mutual understanding, peace ambassador, peace-making mission

\section{INTRODUCTION}

The tourism industry gives a lot of benefit to countries in Asia. As provider of tourism destination, many countries in Asia view tourism as an economic comodity. The fruitful contribution of tourism can range from economy to culture of the countries. The more tourists visit a country, the better economy will be. Countries in Asia compete each other to attract tourists from over the world to visit their countries. They attract them by means of a variety of effort such as providing a good accommodation, a fascinating tourism destination, an attractively cultural entertainment and many delicious culinary. They also promote their tourism destination and object through a social media, television, magazine, brochure and many other advertisement. Through tourism industry, they do all out to raise foreign exchange for their countries and money for the people. That is a common sense of the tourism provider in Asia. They provide tourism destination and their accommodation and they get benefit from this business

As tourist spending lots enough of money, they want to enjoy the beauty of tourism destination they visit. Not only do they enjoy the tourism objects but they also enjoy the hospitality of the people, stay some days in that region. They need hotel and a seamless travel and also delicious culinary. In short, the tourists want to get a maximum pleasure of their travelling. After that they come back to the home country. That is a usual description of a common tourist. They spend their money and get pleasure.

In responding to a new approach for beautiful tourism, the concept of tourism needs improving more in the level of its function, not only for a foreign exchange but also for a peace making. The peace-making mission through tourism is a very strategic way for a beautiful tourism. In addition to this, every tourist in Asia should be as a peace ambassador. The concept of peace-making tourism should be disseminated as soon as possible as a new approach for beautiful tourism. 
The current news of tourist's misconduct in Bali makes all of us very surprised and also aware of the important function of tourist as a peace ambassador. In May 2, 2016, the tourist, Amokrane Sabet from Italia, killed the local police when the police wanted to arrest him due to his bad manner during in Bali and exceeding the time limit stay in Indonesia. The phenomenon shows us that not all tourists realize that their existence in other country is actually as the representative of their home country. By that incident, it might make bad image to his country. They should be polite, wise and in a good manner during at abroad. Learning from that incident, we should insist again that as tourist he or she should place their significant position properly as a peace envoy or ambassador. They might spread out a seed of peace whereever and whenever they visit and interact with local people in a tourism destination.

\section{THEORETICAL FRAMEWORK}

The conceptual proposal of the creative tourism plus is based on the following theories as follows. According to Sarup (1996: 140), he argues that culture is not something fixed and frozen as the traditionalists would have us believe, but a process of constant struggle as cultures interact with each other and are affected by economic, political and social factor. His argument can be interpreted that everything always changes including the concept of tourism. Viewed from its history, the concept of tourism changes ranging from beach tourism, cultural tourism and creative tourism.

Based on the discussion report of the Planning Meeting for "2008International Conference on Creative Tourism" in Santa Fe New Mexico on October 25 - 27, 2006, beach tourism is considered as the first generation of tourism. In this concept, people come to a place for relaxation and leisure; the second generation is cultural tourism oriented toward museums and cultural tours. Creative tourism involves more interaction, in which the visitors has an educational, emotional, social and participative interaction with the place, its living culture, and the people who live there they feel like citizen. This third generation requires that managers also evolve, recognizing the creativity within their city as a resource, and providing new opportunies to meet the evolving interest of the tourists.

In addition to this, Creative Tourism New Zealand (CTNC) conceptualizes creative tourism as a more sustainable form of tourism that provides an authentic feel for a local culture through informal, hands-on workshop and creative experiences. Workshop takes place in small groups at tutors' home and place of work; they allow visitors to explore their creativity while getting closer to local people. By being closer to local people, tourists have potential to interact intensively with them and it enables both of them to build a mutual relationship.

Based on the concepts above, the creative tourism needs improving as a peace-making tourism. It means that tourists not only feel like citizen but also are required to be a peace ambassador. They should spread seed of peace to the local people when they interact with them. So there is a very close relationship between tourism and peace.

Concerning with peace, Galtung (1964: 2) categorized it into two types; they are negative and positive peace. Negative peace is the absence of violence and absence of war and the positive peace is the integration of society. The tourist, tourism and local people as the provider of creative tourism are the elements of political, economic, cultural interaction. The interaction of those elements form the so-called human integration. Those elements should be pushed to form a peacemaking tourism and to function tourist as a peace ambassador.

\section{DISCUSSION}

The concept of peace-making tourism is still strange in tourism industry in the world. Perhaps some say that it is impossible to make it come true. They think the duty of peacemaking process does not lay on them. It seems that they do not realize that duty. They might think that they spend much money for travelling and in return they can enjoy a nice destination, seamless travel and hospitality of the people. From now on, they should be aware that the tourists have a moral and social responsibility to maintain peace with the local people they visit.

A peace-making mission in a creative tourism is very important in Asia. The creative tourism as described by Urry (in Richard and Wilson, 2007) goes beyond the general tourist gaze and involves deeply the tourists in the cultures cape of the destination, where they take part in different activities - crafts, arts, culinary and other creative activities, thus creating a close link between the tourists, the local population and its cultural heritage. From Urry's description, there are some aspects in creative tourism having potential to push tourist as peacemaking envoy. Those aspects are to involve deeply the tourists in the cultures cape of the destination, to take part in different activities such as crafts, arts, and other creative activities and to create a close link between the tourists, the local population and its cultural heritage.

There are some aspects in Urry's concept of creative tourism. In interpreting the first aspect of creative tourism, the concept enables the tourist involve deeply in the cultures cape in Asia. Involving in cultures cape in Asia means the tourists can learn, know and understand as well many cultures in Asian countries, such as Indonesia, Malaysia, Brunei, Thailand, Vietnam, Philipina, China and the like. The cultures cape covers the belief system, religion, social values and norms and also the local wisdom of the people. By involving the Asian cultures cape, the tourists can understand better the people in this region. It ignite a sense of respect, toleration and love as well.

The next aspect is taking part in different activities such as crafts, arts, and other creative activities. Taking part in crafts means that tourists involve with the local people to make a certain handy craft like painting umbrella, painting batik, making a traditional wood crafting and many other crafts. In arts, tourists can learn with the professional local people to dance Srimpi from Surakarta, Kecak from Bali and many other dances from countries in Asia. From those activities, the tourist may have an intensive interaction with the local poeple and they might admire and appreciate the local people having varieties of craft. It can also stimulate the tourists to give more sympathy to the people they visit. 
In addition to this, the tourist may participate in other creative activities. The statement implies that there is a wider opportunity to create an agenda in the frame of creative tourism. The frame of creative tourism, according to Pine and Gilmore (1999), is based on "experiencing" , "participating" and "learning". This puts creative tourism as the next generation of cultural tourism that satisfies the higher level need of self-actualization with a primary focus of active skill development

The last aspect is creating a close link between the tourists, the population and its cultural heritage. It can be interpreted that the tourists have possibility to make a memorable, emotional relationship with the people in Asia. To link each other is very important to maintain togetherness and unity. Through a close and tight relation, they can create a humanistic interaction that possibly moves on a mutually strong communication.

The aspects above strongly enable to improve the creative tourism as a means of peace-making mission. If they are blended with Galtung's (1964: 2) concept of peace, namely negative peace and positive peace, it is optimistic that the future tourism can be conceptualized as a peace-making tourism. It means that there is an opportunity to improve creative tourism into a newly expanded tourism model. Concerning with this model, the tourists are not only supposed to be a consumer of a tourist's destination but also to be a peace ambassador. They come and visit the destination, they are demanded to spread out a seed of peace. They experience, participate, and also learn the authenticity of the local people's culture, tradition and aspects of life. By doing so, the tourists are directed to expand their function and roles as peace ambassador. It at least begins from Asia.

\section{CONCLUSION AND SUGGESTION}

From the above discussion, it can be concluded that the creative tourism needs improving for a sustainable and wonderful tourism in Asia. Tourism has a great prospect for an economic, social, culture, and also political benefit. For economic benefit, tourism in Asia gives many advantages of money exchange for the countries and of better life for the people. For social benefit, by tourism, there are a lot of tourists come and visit the tourism destination in Asia. Their coming enables the local people in Asia interact with them friendlily. Such interaction might generate a mutual relationship among the tourists and the local people. It would strengthen their friendship in the future.

For cultural benefit, tourism attracts people not only to come and visit but also make a direct interaction with the local people, stay in the place of the local people for certain period of time, participate in day-to-day life of the local people and also experience an authenticity of the local people culture. By doing so, they can share their culture each other and by understanding their cultures, a seed of peaceful feeling will grow. Then it will also strengthen the people unity. For political benefit, tourism gives so many contributions of political affairs of the Asian countries. It is believed that tourism can be a parameter whether a country is peaceful or not. The more tourists visit a country, the more peaceful the country will be. In short tourism has a very close relation with the political condition of Asian counties. It is very important to sustain the political relation among countries in Asia also in the world in the framework of creating tourism for a peace development.

\section{REFERENCES}

[1] Galtung, J. 1964. An Editorial. Journal of Peace Research, 1 (1), 1-4.

[2] Ohridska-Olson. 2010. Creative Tourism Business Model And Its Application In Bulgaria.

[3] I Pine, B. J. II., H. J. Gilmore. 1999. The experience economy: Work is theatre and every business a stage. Boston, MA: Harvard Business School Press

[4] Richards, Greg and Wilson, Julie. 2007. Tourism, Creativity and Development. USA: Routledge.

[5] R Sarup, M. 1996. Identity, Culture and the Postmodern World, Edinburgh: Edinburgh University Press.

[6] Smith, Melanie K. 2003. Issues in Cultural Tourism Studies.USA: Routledge

[7] UNESCO.2006. Planning Meeting for "2008International Confrence on Creative Tourism". USA: Santa Fe New Mexico on October 25 - 27, 2006 .. 